This article was downloaded by: [Dr Doriedson Gomes]

On: 09 July 2012, At: 09: 12

Publisher: Taylor \& Francis

Informa Ltd Registered in England and Wales Registered Number: 1072954 Registered office: Mortimer House, 37-41 Mortimer Street, London W1T 3J H, UK

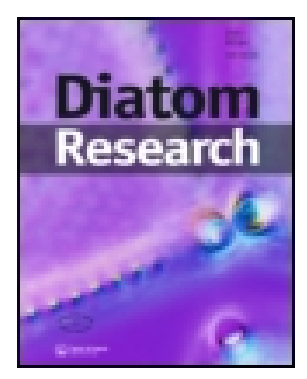

\title{
Diatom Research
}

Publication details, including instructions for authors and subscription information:

http:// www.tandfonline.com/loi/tdia20

\section{Father Zimmermann (1871-1950): the first Brazilian diatomist}

Doriedson Ferreira Gomes ${ }^{a}$, Oberdan Caldas ${ }^{a}$, Eduardo Mendes Da Silva ${ }^{a}$, Peter Andrew Gell ${ }^{b} \&$ David M. Williams ${ }^{c}$

${ }^{a}$ Instituto de Biologia, Universidade Federal da Bahia, Salvador, Brazil

${ }^{b}$ Center for Environmental Management, University of Ballarat, Ballarat, Australia

c Botany Department, The Natural History Museum, London, UK

Version of record first published: 05 J ul 2012

To cite this article: Doriedson Ferreira Gomes, Oberdan Caldas, Eduardo Mendes Da Silva, Peter Andrew Gell \& David M. Williams (2012): Father Zimmermann (1871-1950): the first Brazilian diatomist, Diatom Research, DOI: 10. 1080/ 0269249X. 2012.698646

To link to this article: http:// dx.doi. org/ 10.1080/ 0269249X. 2012.698646

\section{(iFirst}

\section{PLEASE SCROLL DOWN FOR ARTICLE}

Full terms and conditions of use: http://www.tandfonline.com/page/terms-and-conditions

This article may be used for research, teaching, and private study purposes. Any substantial or systematic reproduction, redistribution, reselling, loan, sub-licensing, systematic supply, or distribution in any form to anyone is expressly forbidden.

The publisher does not give any warranty express or implied or make any representation that the contents will be complete or accurate or up to date. The accuracy of any instructions, formulae, and drug doses should be independently verified with primary sources. The publisher shall not be liable for any loss, actions, claims, proceedings, demand, or costs or damages whatsoever or howsoever caused arising directly or indirectly in connection with or arising out of the use of this material. 


\title{
Father Zimmermann (1871-1950): the first Brazilian diatomist DORIEDSON FERREIRA GOMES ${ }^{1 *}$, OBERDAN CALDAS ${ }^{1}$, EDUARDO MENDES DA SILVA $^{1}$, PETER ANDREW GELL ${ }^{2} \&$ DAVID M. WILLIAMS ${ }^{3}$
}

\author{
${ }^{1}$ Instituto de Biologia, Universidade Federal da Bahia, Salvador, Brazil \\ ${ }^{2}$ Center for Environmental Management, University of Ballarat, Ballarat, Australia \\ ${ }^{3}$ Botany Department, The Natural History Museum, London, UK
}

\begin{abstract}
This paper describes the scientific life of Father Zimmermann, Brazil's first diatomist. Father Zimmermann, a Jesuit priest born in Ehingen, Germany in 1871, studied theology in Britain in the early 20th century. His scientific life began in Portugal where, with other Jesuits, he founded the scientific journal Brotéria, for which he wrote several papers on diatoms. After the fall of the Portuguese monarchy in 1910, several conservative priests, including Zimmermann, immigrated to Brazil. In Brazil, he became a teacher at the Padre Antonio Vieira School in Salvador in the state of Bahia, where he taught a myriad of disciplines. In addition to his teaching and religious activities, along with his fellow priests, Zimmermann continued to edit Brotéria. By the end of his career in Portugal, Zimmermann had described a total of 69 new but not all valid diatom names. In 1913, Zimmermann began a series of articles entitled 'Contribuição para o estudo das diatomaceas dos Estados Unidos do Brazil' (Contribution to the study of diatoms of the United States of Brazil), in which he described two new genera and 49 new species from rivers, lakes, wetlands, reservoirs and beaches in the states of Bahia, Minas Gerais, Rio de Janeiro, São Paulo and Rio Grande do Sul. In addition to his taxonomic descriptions, Zimmermann who was an accomplished naturalist, also wrote about diatom movements and evolution. His diatom studies were compiled in a book entitled Diatomées, which has never been published. Father Zimmermann's contribution to the study of diatoms deserves proper recognition. This paper aims to serve such purpose. Farther Zimmermann died in Salvador in 1950.
\end{abstract}

Keywords: Father Zimmermann, diatomist, marine and freshwaters waters, Brazil

\section{Introduction \\ Biographical details}

The priest, teacher, naturalist and researcher Karl Zimmermann (28 March 1871-21 October 1950) was born in Ehingen in the Kingdom of Wuerttemberg (currently the state of Baden-Württemberg, Germany) and died in Salvador, Brazil (Fig. 1). He divided his life between his religion, his teaching as a professor of Latin, music, German, physics, chemistry, history, geography, design and geometry at the San Fiel College, Louriçal do Campo and San José do Porto in Portugal, and his work as a diatom researcher. Farther Zimmermann entered the Society of Jesus by way of the Province Ignatian of Lyon on 7 September 1890, obtained his ordination on 2 February 1908 and, soon after, joined the monastery of Barros da Torre where he was responsible for coordinating the music and where he earned a degree in humanities. He began teaching in 1895. While working as a teacher between 1896 and 1899, he studied philosophy. He went on to study theology, dividing his time between England and Ireland, and completing his humanities education in 1905 (Franco 2003).
News of Zimmermann's death was given in three obituaries, published in two journals of the city of Salvador, capital of Bahia state: two in A Tarde (23 October 1950 and 25 October 1950) and one in Diário de Notícias (7 November 1950), the latter being written by one of his students. By 1920, the priest had asked for his secularization, so that he could cease to be a Jesuit and become a diocesan priest. No obituary was published in Brotéria. This work is, therefore, an attempt to shed light on a few of the various aspects of his life, in particular, his scientific work.

Although of German origin, he used the name Carlos Zimmermann (a translation into Portuguese of his Christian name) in articles published in Brotéria, probably because he spent most of his life in Portuguese-speaking countries. It is of interest to note that his name appears in several databases, such as the California Academy of Science (CAS) Catalogue of Diatom Names and Algaebase, in different forms: Zimmermann, S.J.C.; Zimmerman, C; Zimmermann, C.; C. Zimmermann, C. Zimmermann, S.J.; or S.J.C. Zimmermann. The spelling 'Zimmerman' is, certainly a simple orthographic error for Zimmermann.

\footnotetext{
*Corresponding author. Email: dfgomes@ufba.br

(Received 3 May 2012; accepted 28 May 2012)

ISSN 0269-249X print/ISSN 2159-8347 online

(C) 2012 The International Society for Diatom Research

http://dx.doi.org/10.1080/0269249X.2012.698646

http://www.tandfonline.com
} 


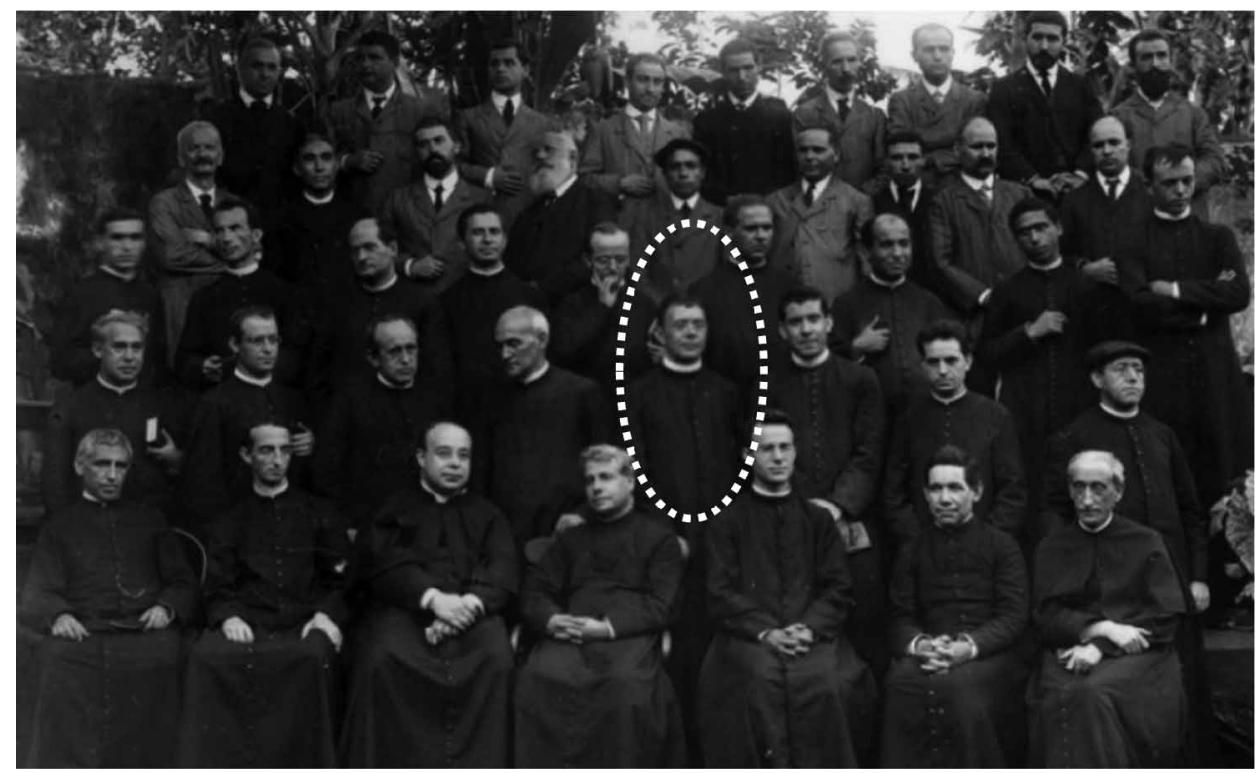

Fig. 1. Father Karl Zimmermann (1871-1950). Photo courtesy of Father Geraldo Antonio Almeida S.J., Salvador, Bahia.

The 'S.J.' is a reference to the Society of Jesus, as Zimmermann was a Jesuit priest, abbreviated as S.J., SJ, SI or s.i., (the latter two abbreviations reflecting the Latin name of the order). Thus it is correct to refer to Zimmermann as: Karl [Carl, Carlos] Zimmerman (1871-1950) [S.J. (Society of Jesus, Societas Iesu, S.J., SJ, s.i.). The International Plant Names Index (IPNI, http://www.ipni.org/ipni/ authorsearchpage.do) offers the abbreviation 'C. Zimm.'. It would seem appropriate that, in future, current databases standardize the spelling of the name and use of the accepted abbreviation for his work.

\section{Early work}

Zimmermann's scientific publishing began with a series of four articles entitled 'Microscopia vegetal' (Zimmermann 1902, 1903, 1904, 1906b). In this series, which was dedicated to encouraging high school teachers to use microscopes in their classes, Zimmermann commented on the use of the microscope in Portuguese schools, especially public high schools. He also emphasized the importance of using a microscope as a teaching resource, linking theory with practice. Zimmermann's interest in teaching and research is evident from these papers. He discusses the parts of the microscope, the various accessories available and their use: camera lucida, Abbe drawing apparatus, clipboards, various microtomes, with comments on their advantages and disadvantages. He then relates in great detail all the relevant methods of making slides for microscopic observations, including fixation, dehydration, infiltration, inclusion, gluing and the colouring of plant material. He outlines some rules and good practice for teachers when making microscopic observations: they should be made in a laboratory, which is the best place for the microscope; the kinds of objectives, lighting, etc. He concludes with drawings obtained from his slides: pollen, a leaf of Pinus, Micrasterias, Closterium and Zea mays.

In addition to publishing his diatom studies, Zimmermann wrote a paper on the observatory at San Fiel College (Zimmermann 1902b); an article about 'Epidascopio', the database of the time (Zimmermann 1903b); an article on the anatomy of an insect gall produced by a given plant (Zimmermann 1906a); a contribution to the Cecidians of Kent (Zimmermann 1907); a paper describing the relationship of the Jesuits and astronomy (Zimmermann 1906b); and reviews of scientific books (Zimmermann 1909a, 1912).

\section{The diatoms of Portugal and Madeira}

Between 1906 and 1910, Zimmermann began a series of papers on the study of diatoms (Zimmermann 1906c, 1909a, b, 1910b). These were a compilation of diatoms identified in Portugal by other researchers, but included new discoveries made by Zimmermann. In his first diatom article, Zimmermann sought collaboration in the collection of samples from different regions of Portugal:

Como não me é possivel percorrer todas as regiões de Portugal, peço obsequiosamente a coadjuvação de todos os que se interessem por este genero de estudos. Pequeno é o incommodo. Basta recolher as algas ou limos que se encontram nos regatos, charcos, poços, rios e praias do mar, ás quaes andam associadas as Diatomaceas; deixam-se seccar para mais facilmente se poderem remetter pelo correio, e póde assegurar-se que qualquer insignificante colheita conterá grande abundancia d'estes seres admiraveis. De boa vontade enviarei aos colleccionadores uma preparacao de todas as especies encontradas na colheita, se assim se desejar. (Zimmermann 1906c: 245). 
As I cannot go to all the regions of Portugal, I humbly request the assistance of all who are interested in such studies. It should be little trouble. Simply collect the algae or slime found in streams, ponds, wells, rivers and beaches of the sea, where diatoms are associated; let them dry out so that they can be easily sent by mail, and it is certain that any minor collection will contain a great abundance of these wonderful beings. (Our translation).

In these papers, Zimmermann presented 27 diatom families, 73 genera and 400 species, 340 of which were first species records in Portugal. Significantly, before Zimmermann's work, only 60 species were known in Portugal. Zimmermann also studied the diatoms of Madeira, where he recorded 211 different species (Zimmermann 1909c, 1911). Zimmermann's final contribution while living in Portugal was an article aimed at a lay audience, which explained where to find, how to prepare and how to mount diatoms permanently onto slides (Zimmermann 1910a). By the end of his studies in Portugal and its territories, Zimmermann had described 19 new diatom species (Appendix).

\section{The diatoms of Brazil}

On 5 October 1910, the Republic of Portugal replaced the monarchy, which led to the departure of several conservative priests from Portugal to Brazil. In 1911, Zimmermann, with others priests, founded and became a teacher at Padre Antonio Vieira School, a traditional, private religious high school that still exists today, where he taught history, trigonometry and languages, among other disciplines. In addition to his teaching and religious activities, he continued to edit Brotéria with his fellow priests and added a subtitle, the Portuguese-Brazilian Journal, which transformed Brotéria into one of the first Brazilian scientific journals.

In 1913, Zimmermann started a series of articles entitled 'Contribuição para o estudo das diatomaceas dos Estados Unidos do Brazil' (Contribution to the study of diatoms of the United States of Brazil) (Zimmermann 1913, 1915b, c, d, 1916a, b, 1917b, 1918a, c, d), in which he eventually described 49 new species (some of them described in Zimmermann 1917a, 1918b, 1919b).

As in Portugal, Zimmermann continued his studies by compiling data from diatomists who had worked with samples taken from Brazil. Many descriptions of diatom species did not include a sample location or collector's name, so Zimmermann took care to produce as complete a bibliography as possible (Zimmermann 1913). In his first sentence, Zimmermann wrote:

Não me consta que jamais diatomologo algum se occupasse ex professo do estudo das diatomaceas do vasto territorio do Brazil. (Zimmermann 1913: 149).

To the best of my knowledge no other naturalist has taken care of the study of diatoms in the vast territory of Brazil. (Our translation).
Zimmermann proposed bringing together the scattered diatom floristic treatments from the countless publications describing diatoms found in Brazil. At that time, there was documentation for 15 families, 35 genera and 93 species (Zimmermann 1913). While in Brazil, Zimmermann also continued publishing papers about his time in Portugal (Zimmermann 1914a, b).

During seven years of Brazilian diatom studies, Zimmermann analysed samples from the states of Bahia, Minas Gerais, Rio de Janeiro, São Paulo and Rio Grande do Sul. The samples were collected by Zimmermann and nine collaborators from rivers, lakes, wetlands, reservoirs and the sea (Todos os Santos Bay, Santos and Guarujá).

Zimmermann published two further compilations in Annaes do $5^{\circ}$ Congresso Brazileiro de Geographia (5th Brazilian Congress of Geography) in Salvador. In the first, Zimmermann recorded diatoms from Todos os Santos Bay, where he collected three plankton samples and identified 35 species belonging to 23 genera and 14 families (Zimmermann 1916c). In the second, Zimmermann described diatoms found in Dique do Tororó, a reservoir constructed by the Dutch in 1624 to protect the city against pirates (Zimmermann 1916d). In Dique do Tororó, Zimmermann found 26 diatom species, one of which was planktonic (Cyclotella meneghiniana Kützing), with the others found on the water hyacinth, Eichhornia crassipes (Martius) Solms-Laubach.

\section{Beyond taxonomy}

Almost all of Zimmermann's studies were devoted to taxonomy, presenting identifications (with and without descriptions of species and illustrations) and information on the collecting sites. However, he did introduce the reader to some aspects of the ecology of diatoms (Zimmermann 1916c). In the introduction to 'Florula diatomologica do plankton superficial da bahia da Cidade do Salvador' (Zimmermann 1916c), he discusses the importance of the phytoplankton community for the trophic economy of aquatic systems, and provides data on the cycling of silica, citing calculations by Otto Zacharias (but not the year) on Lake Plön. He also discussed the sedimentation process of diatom valves and the formation of deposits, citing several with the metric variations in their thickness. There are paragraphs discussing variables, in particular, the weight of diatomaceous earth and water, form resistance and viscosity of the medium, which interfere with the sedimentation process, explaining that, because bodies are denser than water they can remain suspended in the liquid medium. Finally, Zimmermann discusses the shifting opinions concerning evolution. This is discussed in more detail below.

Zimmermann also studied the movements of diatoms (Zimmermann 1916d). He observed Navicula lanceolata (C. Agardh) Kützing trying to pass under a sand grain. The diatom repeated the movements of advancing and retreating six times, always along the main axis, until it passed 
under the grain on its seventh attempt. Zimmermann used this evidence to reject the hypothesis, held at the time, that diatoms moved by the detachment of gas bubbles through the tiny pores of the inner protoplasm. Almost 100 years after Zimmermann's observation, there are two hypotheses about the displacement of diatoms. The first postulates that the release of mucus is responsible for the adhesion and displacement of the cell (Wetherbee et al. 1998); the second postulates that microfibrils are responsible for movement (Drum \& Hopkins 1966, Edgar \& Pickett-Heaps 1983). A third hypothesis, proposed by Bertrand (2008), attempts to reconcile both: propulsion by microfibrils and the release of mucus.

\section{Evolution}

Zimmermann used diatoms to discuss and demonstrate his position on the theory of evolution (Zimmermann 1916c). It is clear when reading the introduction to his article published in Annaes do $5^{\circ}$ Congresso Brazileiro de Geographia that he changed his position on the theory of evolution during his life.

In Zimmermann (1916c), the last 12 paragraphs of the Introduction are dedicated to presenting his position on evolution. In one of the paragraphs he wrote:

Confesso, que em tempos fui um enthusiastico defensor da theoria da evolução, e ainda lhe não lhe sou adverso. A adaptação quer activa, quer passiva, quer funccional, sem duvida existe e tem exercido um papel preponderante, quer na ontogenese, quer na philogenese dos seres organicos. Que ella porém por si só possa explicar esta multiplicidade de seres que povoam o nosso globo, estou hoje longe de admittir. Fui levado a esta maneira de pensar pelos meus estudos especiaes sobre as diatomáceas. (Zimmermann 1916: 451).

I confess, that in time I was an enthusiastic advocate of the theory of evolution, and still am not adverse to it. Adaptations, active, passive or functional, no doubt exist and have played a major role either in the ontogeny or phylogeny of organic beings. But this alone cannot explain the multiplicity of beings that inhabit our globe. I am far from admitting this today. I was led to this way of thinking by my special studies on diatoms. (Our translation).

Zimmermann continues, presenting his disagreement with current evolutionary theory and stating an erroneous view of homogeneity of the aquatic environment, known today as the 'paradox of plankton' (Hutchinson 1961).

Como, pois, explicar a immensa variedade de formas só por meio da adaptação, considerando sobretudo que o influxo do meio é sempre o mesmo ou incomparavelmente menos multiplo do que em terra firme, e que as diatomaceas offerecem naturalmente maior resistencia em virtude da sua carapaça siliciosa e inerte? (Zimmermann 1916: 452).

How, then, can one explain the huge variety of shapes only through adaptation, especially considering that the influence of the medium (water) is always the same or incomparably less variable than on land, and that diatoms naturally offer greater resistance to change because of their siliceous and inert valves? (Our translation).

The main argument Zimmermann uses to confront evolutionary theory is the belief that the fossil record of diatoms is continuous:

Bem sei que ás difficuldades contra o evolucionismo tiradas da paleontologia se responde com o missing link. Muito bem; porém este élo não devia faltar nas diatomaceas. (Zimmermann 1916: 452).

I know that difficulties against evolution drawn from palaeontology are countered by the idea of missing links. Very well, but this link should not be lacking in diatoms. (Our translation).

Zimmermann believed in the indestructibility of the valves; he continued:

Não podemos invocar, como já disse, o missing link. A carapaça das diatomaceas formada por silica pura é, por assim dizer indestructível. Resiste ao calor mais intenso e á acção de quasi todos os ácidos mesmo os mais energi$\cos$. Não podemos, portanto, admittir que uma immensidade de formas intermediarias, desapparecesse pelo influxo de não sei que agentes externos. Estas formas intermediarias, repito, deviam existir, considerando a sua indestructibilidade relativa. (Zimmermann 1916: 452).

We cannot rely, as I have said, on missing links. The valves of diatoms are composed of pure silica, which is indestructible. Resisting the most intense heat and the action of almost all acids, even the most severe. We cannot therefore admit that a multitude of intermediate forms disappeared by the influx of processes unknown. These intermediate forms, I repeat, should be present, considering their relative indestructability. (Our translation).

The data used by Zimmermann to discuss this comes in part from secondary information, since he worked exclusively with recent species. He continued to discuss the issue of the fossil record, expressing an understanding that is now considered incorrect. The oldest fossil record date for diatoms is ca. 190 million years ago (Julius \& Theriot 2010), while the oldest fossil record of life is ca. 4.5 billion years ago.

Conhecemos jazidas de diatomaceas de quasi todas as regiões do mundo desde a epoca em que pela primeira vez se manifestou a vida sobre o nosso globo. E que vemos? (Zimmermann 1916: 452).

We know diatomaceous deposits from almost all regions of the world since the time life first manifested itself on our globe. And what do we see? (Our translation).

Zimmermann argued about the continuity of change expected in the fossil record of diatoms:

Grande numero de especies são em tudo perfeitamente identicas ás especies que hoje povoam os nossos rios, lagos e mares. Até encontramos especies mais perfeitas, e são exactamente estas que no decorrer dos tempos desappareceram.

Como explicar este facto incontestável pela evolução lenta e continua sob o influxo da adaptação? 
Mais. Se esta evolução tivesse existido, haviamos de encontrar as diatomaceas fosseis em estado de confusão tal que uma classificação e identificação de especies se tornasse completamente impossivel em virtude da transição quasi insensivel de uma forma á outra que a adaptação havia de produzir. Porém, estamos longe disto.

Podemos até affirmar que as differentes especies fosseis se differenciam mais pronunciadamente umas das outras do que hoje succede com varias especies. (Zimmermann 1916: 452).

A large numbers of species are all perfectly identical to species now inhabiting our rivers, lakes and seas. We can find more perfect species, and these are exactly like those of the past.

How can this undeniable fact be explained by the slow and continuous evolution under the influence of adaptation?

In addition, if this trend had existed, we would find fossil diatoms in such a state of confusion that classification and identification of species would became completely impossible because of the almost imperceptible transition from one form to another produced via adaptation. But that is far from the truth.

We can even say that the different fossil species differ more sharply from one another than they do from various species today. (Our translation).

It seems, therefore, that Zimmermann did have a conflict between his religious beliefs and the knowledge he derived from science. However, in his closing discussion of evolution he clearly stated that it was not his religious ideas that made him change his position:

Não julgue alguem que me tornei menos favoravel á theoria da evolução em virtude do caracter sagrado de sacerdote catholico que reveste a minha individualidade. Sei muito bem, como naturalista e como theologo que a theoria scientifica da evolução não está de modo algum em opposição com os ensinamentos certos da Egreja catholica. Razões de caracter puramente scientifico e de modo algum theologico operaram esta mudança. (Zimmermann 1916: 452-453).

Do not judge someone who has become less favourable to the theory of evolution because he is a Catholic priest. I know very well, as a naturalist and as a theologian, that the scientific theory of evolution does not in any way conflict with certain teachings of the Catholic Church. Reasons of a purely scientific and theological view operated to affect this change. (Our emphasis and translation).

While it may seem unusual by today's standards to accept that a priest could believe and express confidence in the theory of evolution in public, the truth that species change over geological time has been accepted by most with little doubt. The debate as it stands today is concerned with the mechanisms that attempt to explain the changes. According to Bowler (1985), evolutionary theories fall into five categories: (1) Darwinian natural selection, (2) Lamarckism, (3) orthogenesis, (4) the theory of mutation, and (5) theistic evolution. Some intense religious beliefs held by scientists suggest that change is not random, but could be directed to a predetermined destination through the will of God (Bowler 1985). Thus, Zimmermann, was part of the current thought of the time.

\section{Discussion}

It is not known whether Zimmermann was trained in the identification of diatoms, but we believe that he was selftaught. In his 'Microscopia Vegetal' papers (Zimmermann 1902), he describes the procedure for making observations using a microscope, and it is clear from his writing that there was no authority or mentor involved. Zimmermann was one of seven Jesuit priests that founded the Sociedade Portuguesa de Ciências Naturais (Portuguese Society of Natural Sciences) and he was a member of the Royal Society of Microscopy of London (Romeiras \& Leitão 2012).

By 1919, Zimmermann had compiled the papers he had published in Brotéria to form a book which he entitled Diatomées (the original cover image is shown in Fig. 2); it was never published. In this work, Zimmermann included all the species of diatom that had been reported in Brotéria and he also included additional species. In the prologue, Zimmermann described where an interested reader might find diatoms and how they are collected from plankton and benthic specimens in freshwater or marine environments, as communities or individuals. He also described how diatoms can be cleaned of organic material and how to prepare permanent slides. He wrote about the biology and morphology of diatom frustules, and advised researchers to keep a diary of their observations in the laboratory and in the field; he discussed the instruments needed to study diatoms, microscope manufacturers and the shops where photographic equipment could be bought. The second part of the book was devoted to diatom taxonomy, including keys to the identification of family, genus and species; he included descriptions, photographs and/or drawings of the species.

No references for species identification were provided in Zimmermann's articles; however, we believe that some books - which he indicated were indispensable bibliographies for species identification - should form part of the references: Kützing (1844), Ehrenberg (1854), Smith (1853, 1856), Rabenhorst (1864), Donkin (1870), Brun (1880), Van Heurck (1880), De Toni (1891), Héribaud (1893), Peragallo (1891), Peragallo \& Peragallo (1897-1908) and Schmidt et al. (1874-1959), among others.

While still in Portugal, Zimmermann was responsible for the creation of the herbarium at San Fiel College. He was director of the herbarium from 1897 to 1904 and from 1907 to 1910 , when the priests were expatriated and the herbarium was transferred to the University of Coimbra (Lado \& Pando 1989, Tavares 1924). According to Tavares (1924), at this time, the herbarium held 5000 samples of fungi, lichens, mosses, phanerogams and diatoms (3000 diatoms species are included in the collections bought from Tempère and Peragallo). The pitfalls of curating the diatom collection 


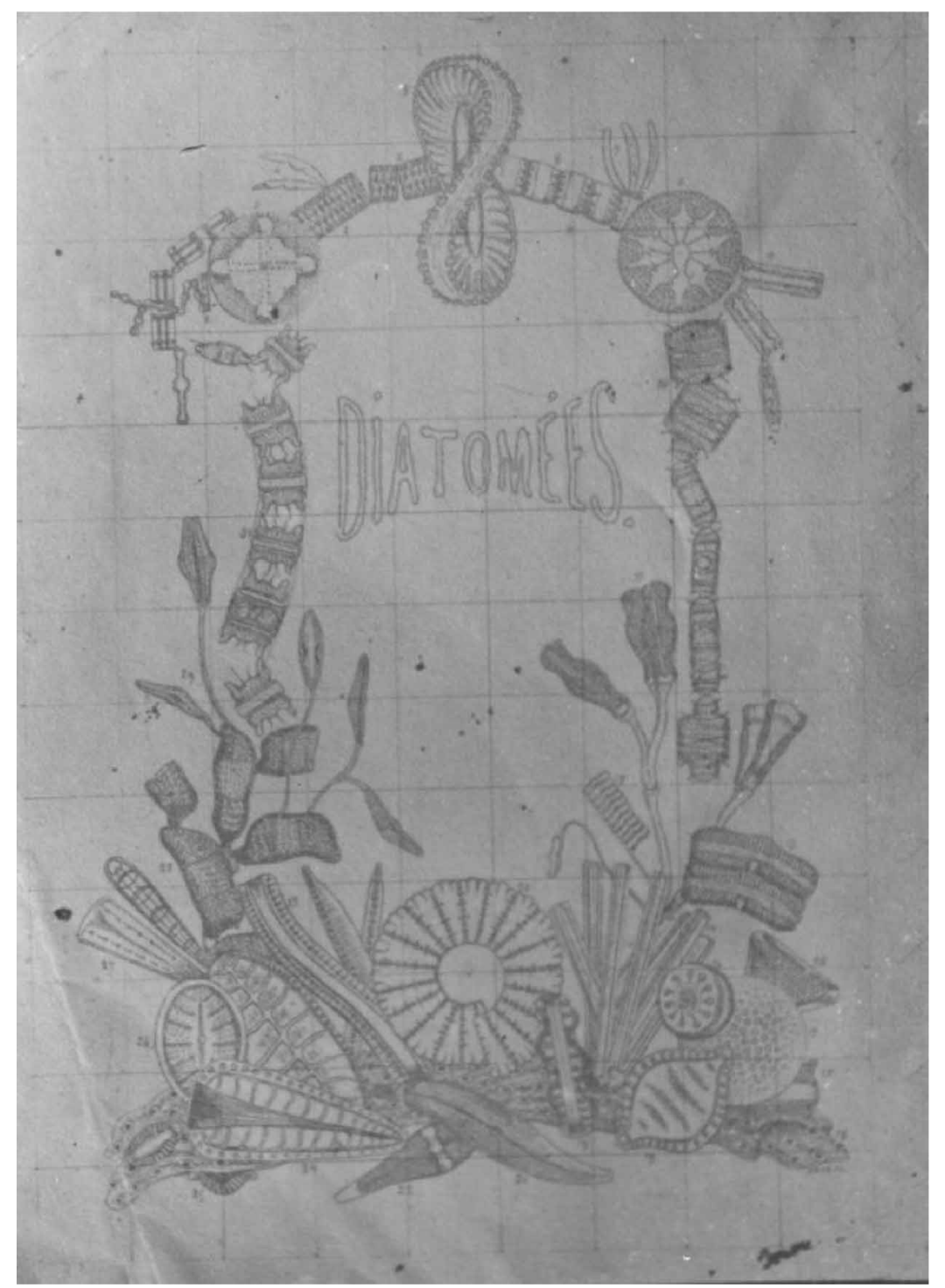

Fig. 2. Cover image of the original manuscript for Zimmermann's Diatomées (1919).

(and other hazards, such as his persecution by a sniper when he was fleeing Portugal) were recorded by Zimmermann in 1914. The herbarium collection contained several samples from Portugal and its overseas territories. Of the collections, microscopes and library that formed his laboratory, only his collections and some manuscripts were restored to Zimmermann, thanks to a friend unnamed. The new provisional government of the Republic restored only one publication to Zimmermann (1914). Henriques (1922), responsible for the transfer of the collections, does not mention the diatom collection, and therefore, its fate is unknown. Unfortunately, we were not able to locate, in Brazil, any slides used by Zimmermann in his studies. However, Almeida includes an original photograph of a diatom that Zimmermann identified (de Almeida 2002: nv42, p. 181), and we have found 21 original photographs of Zimmermann's diatoms.
The series of studies on diatoms from Brazil was concluded in 1919. It is interesting to note that this date coincides with Zimmermann's trip, together with the Portuguese priest Luiz Vieira, to the city of Barreiras, located $905 \mathrm{~km}$ from Salvador, Bahia; Luiz Vieira was appointed vicar of the city of Barreiras (Anonymous 2009). Apparently, these years were dedicated to helping Father Vieira complete the Church Matriz de São João Batista, which began in 1892 and was completed in 1925 (Anonymous 2009), in addition to teaching. Anonymous (2009) reports teaching by a Father Carlos Zimmerman (sic, surely a typo) in the school - cited as a private school for the study of languages (journal 'Cidade de Barreiras' for the year 1924; Anonymous 2009), and there are reports that Father Carlos Zimmerman (Anonymous 2009) took over as director and professor at the federal vocational establishment 'Aprendizado Agrícola', at the time (1920s) the most important 
school in the town of Barreiras. The school was closed after nine years, for political reasons (Anonymous 2009).

In addition to the training of students and his contribution to science, Zimmermann founded a meteorological observatory in the college of San Fiel, which sent bulletins twice daily by telegraph to the central station in Lisbon, Portugal (Zimmermann 1914).

Having evaluated his work, we recognize Zimmermann as a polyglot and polymath and pay tribute to him as one of the first diatomists, and perhaps the first phycologist, from Brazil, who dedicated part of his life to unveiling the microscopic world of algae, especially diatoms. Although his importance in the diatom field is indisputable, some of his writings remain unpublished. A deeper analysis of his many works will provide many new insights into the thoughts of this brilliant naturalist.

\section{Acknowledgements}

We would like to thank the librarian Amélia Valente at the Antonio Vieira College for facilitating our access to Father Zimmermann's articles and photographs. A special thank to Father Geraldo Antonio Coelho de Almeida whose discourse about the history of the Jesuits was most enlightening. We also would like to thanks to Charbel El-Hani and Nei Nunes Neto for discussions about evolutionary thinking of that time.

\section{References}

All Zimmermann's references are quoted in the Appendix.

AGARDH C.A. 1827. Aufzählung einiger in den östreichischen ländern gefundenen neuen gattungen und arten von algen, nebst ihrer diagnostik und beigefügten bemerkungen. Flora 10: 625-640.

ANDRAdE M.H. \& TeIXEIRA C. 1957. Contribuição ao conhecimento das diatomaceas do Brasil. Boletim do Instituto Oceanográfico 8: 171-215.

AnONymous. 2009. Pioneiros da educação [online]. Prefeitura de Barreiras. Available from: http://www.barreiras.ba.gov.br/ historia-pdf/pioneirosedu.php [Accessed 25 January 2012].

BERKELEY M.J. 1833. Cleanings of British algae; being an appendix to the supplement to English Botany. C.E. Sowerby, London. $50 \mathrm{pp}$.

BERTRAND J. 2008. Mouvements des diatomées VIII: synthèse et hypothèse. Diatom Research 23: 19-29.

BOWLER P.J. 1985. The eclipse of Darwinism: anti-Darwinian evolution theories in the decades around 1900. Johns Hopkins University Press, Baltimore. 291 pp.

BRÉBISSON A de. 1838. Considérations sur les diatomées et essai d'une classification des genres et des espèces appartenant à cette famille. Brée l'Ainé Imprimeur-Libraire, Falaise. 22 pp.

BRUn J. 1880. Diatomées des Alpes et du Jura et de la région suisse et française des environs de Genève. Imprimerie Ch. Schuchardt, Genève. 146 pp.

BRUN J. 1895. Diatomées lacustres, marines ou fossiles, espèces nouvelles ou insuffisamment connues. Le Diatomiste 2: 14 17, 19-20.

BRUn J. 1901. Diatomées d'eau douce de l'île Jan Mayen et de la côte est du Groenland, récoltées par l'expédition suédoise de
1899. Bihang till Kongliga Svenska Vetenskaps-Akademiens Handlingar 26: 1-22.

Castel-Branco C. 2004. Félix de Avelar Brotera: botaniste Portugais (1744-1828). Centre Culturel Calouste Gulbenkian, Paris. 329 pp.

CARTER J.R. 1966. Some freshwater diatoms of Tristan da Cunha and Gough Island. Nova Hedwigia 11: 443-483.

Catalogue of Diatom Names. California Academy of Sciences. Online version updated 22 January 2012. Available at: http://research.calacademy.org/research/diatoms/names/ index.asp

CLEVE P.T. 1893. Sur quelques espèces nouvelles ou peu connues. Le Diatomiste 2: 12-16.

Cleve P.T. 1894. Synopsis of the naviculoid diatoms. Part I. Kongliga Svenska-Vetenskaps Akademiens Handlingar 26: 1-194.

Cleve P.T. 1895. Synopsis of the naviculoid diatoms. Part II. Kongliga Svenska-Vetenskaps Akademiens Handlingar 27: $1-219$.

Cleve-Euler A. 1948. Süsswasserdiatomeen aus dem Feuerland von Prof. Väinö Auer Gesammelt. Acta Geographica 10: 3-6.

DE Almeida S.B. 2002. Negativos em vidro: coleção de imagens do Colégio Antônio Vieira, 1920-1930. Edufba, Salvador. $372 \mathrm{pp}$.

DE Toni G.B. 1891. Sylloge algarum omnium hucusque cognitarum. Vol. II. Sylloge Bacillariearum. Section I. Rhaphideae. pp. [i-iii]. [i]-cxxxii, 1-490. Patavii [Padua]: Typis Seminarii.

DonKIN A.S. 1870. The natural history of the British Diatomaceae. Part 1. J. Van Voorst, London. 24 pp.

DRUM R.W. \& Hopkins J.T. 1966. Diatom locomotion, an explanation. Protoplasma 62: 1-23.

Edgar L.A. \& PicketT-Heaps J.D. 1983. The mechanisms of diatoms locomotion an ultrastructural study of the motility apparatus. Proceedings of the Royal Society of London B 218: 333-343.

EHRENBERG C.G. 1853. Über einige neue Materialien zur Übersicht des kleinsten Lebens. Bericht über die zur Bekanntmachung geeigneten Verhandlungen der KöniglichPreussischen Akademie der Wissenschaften zu Berlin 1853: 505-533.

EHRENBERG C. G. 1854. Mikrogeologie das Erden and Felsen schaffende wirken des unsichtbar kleinen selbstandigen Lebens auf der Erde. Leipzig.

EHRENBERG C.G. 1856. Über das mikroskopische leben der centralen landflächen Mittel-Afrika's. Monatsbericht der Königlichen Akademie der Wissenschaften zu Berlin 1856: 323-338

FRANCO J.E. 2003. Os directores da Brotéria: Carlos Zimmermann. In: Fé, Ciência, Cultura: Brotéria - 100 anos (Ed. by H. Rico \& J. E. Franco). Editora Gradiva, Lisbon. 561 pp.

Frenguelli J. 1933. Contribuciones al conocimiento de las Diatomeas Argentinas. VII. Diatomeas de la región de los Esteros del Ybera (en la Provincia de Corrientes). Anales del Museo Nacional de Historia Natural 37: 365-475.

Frenguelli J. 1945. El Platense y sus diatomeas, Las diatomeas del Platense. Revista del Museo de La Plata (Nueva Serie), Sección Paleontología 3: 77-221.

HenRIQues J.A. 1922. As colecções botánicas do Collégio de San Fiel. Boletim da Sociedade Broteriana, Serie 2 1: $1-137$. 
HéRIBAud J. 1893. Les diatomées d'Auvergne. Librairie des Sciences Naturelles, Paris. 255 pp.

HérIBAUd J. 1903. Les diatomées fossiles d'Auvergne (second mémoire). Librairie des Sciences Naturelles, Paris. 166 pp.

HéRIBAUD J. 1920. Les diatomées des travertins d'Auvergne. Avec la collaboration de F. Aspeitia, Comère, Deblok, E. Østrup, M. Peragallo, P. Prudent, A. Rochoux D'Aubert. Bruxelles. 206 pp. [also in: Annales de Biologie Lacustre 10: 5-206].

HustedT F. 1937. Systematische und ökologische Untersuchungen über die Diatomeen-Flora von Java, Bali und Sumatra nach dem Material der Deutschen Limnologischen SundaExpedition. Archiv für Hydrobiologie, Supplement 15: 187 295.

HustedT F. 1939. Die Diatomeenflora des Küstengebietes der Nordsee vom Dollart bis zur Elbemündung. I. Die Diatomeenflora in den Sedimenten der unteren Ems sowie auf den Watten in der Leybucht, des Memmert und bei der Insel Juist. Adhandlungen des Naturwissenschaftlichen Verein zu Bremen 31: 571-677.

HustedT F. 1952. Neue und wenig bekannte Diatomeen. IV. Botaniska Notiser 1952: 366-410.

Hutchinson G.E. 1961. The paradox of the plankton. American Naturalist 95: 137-146.

Julius M.L. \& Theriot E.C. 2010. Diatoms: a primer. In: The diatoms: Applications for the environmental and earth sciences (Ed. by J.P. Smol \& E.F. Stoermer), pp. 23-54. Cambridge University Press, Cambridge.

KrassKe K. 1943. Zur Diatomeenflora Lapplands. Berichte der Deutschen Botanischen Gesellschaft 61: 81-88.

KüTZING F.T. 1844. Die Kieselschaligen. Bacillarien oder Diatomeen. W. Köhne, Nordhausen. 152 pp.

Lado C. \& Pando F. 1989. La colección de Myxomycetes preparada por C. Torrend para el Colegio San Fiel (Portugal). Anales Jardin Botánico de Madrid 46: 173-180.

Lange-Bertalot H., Külbs K., Lauser T., NÖrPel-ÖrPelSCHEMPP M. \& WilLMANN M. 1996. Diatom taxa introduced by Georg Krasske: documentation and revision. Iconographia Diatomologica 3: 1-358.

Metzeltin D. \& Lange-Bertalot H. 2007. Tropical diatoms of South America, 2. Iconographia Diatomologica 18: $1-877$.

Metzeltin D. \& Lange-Bertalot H. 1998. Tropische Diatomeen in Südamerika I. Iconographia Diatomologica 5: 1-695.

Mills F.W. 1934. An index to the genera and species of the Diatomaceae and their synonyms. 1816-1932. Part 15 (Na$\mathrm{Na}$ ), pp. 1081-1161. Wheldon \& Wesley, London.

Moser G., Lange-Bertalot H. \& Metzeltin D. 1998. Insel der Endemiten Geobotanisches Phänomen Neukaledonien (Island of endemics New Caledonia - a geobotanical phenomenon). Bibliotheca Diatomologica 38: 1-464.

Müller O. 1909. Bacillariaceen aus Süd-Patagonien. Botanische Jahrbücher für Systematik 43: 1-40.

PANTOCSEK J. 1892. Beiträge zur Kenntnis der Fossilen Bacillarien Ungarns. Teil III, Susswasser Bacillarien. NagyTapolcsány, Buchdrucherei von Julius Platzko. 42 pls. Available at: http://www.biodiversitylibrary.org/page/14881724

PANTOCSEK J. 1902. Kieselalgen oder Bacillarien des Balaton. Resultate der Wissenschaftlichen Erforschung des Balatonsees, herausgegeben von der Balatonsee-Commission der Ung. Geographischen Gesellschaft 2: 1-112.
PATRICK R. \& REIMER C.W. 1966. The diatoms of the United States, exclusive of Alaska and Hawaii. Volume 1. Fragilariaceae, Eunotiaceae, Achnanthaceae, Naviculaceae. Monograph 13. Academy of Natural Sciences, Philadelphia. 688 pp.

Peragallo H. 1891. Monographie du genre Pleurosigma et des genres alliés. Le Diatomiste 1: 1-35.

Peragallo H. \& Peragallo M. 1897-1908. Diatomées marines de France et des districts maritimes voisins. M.J. Tempère, Micrographe-Editeur, à Grez-sur-Loing. 493 pp., 137 pls.

RABENHORST L. 1864. Flora Europaea algarum aquae dulcis et submarinae. Sectio I. Algas diatomáceas complectens, cum figuris generum omnium xylographice impressis. Lipsiae [Leipzig]: Eduard Kummer. 359 pp.

Romeiras F.M. \& LeITÃo H. 2012. Jesuítas e Ciência em Portugal. II - Carlos Zimmermann S.J. e o ensino da Microscopia Vegetal. Brotéria 174: 113-125.

Schmidt A., Schmidt M., Fricke F., Heiden H., Muller O. \& Hustedt F. 1874-1959. Atlas der Diatomaceen-Kunde. R. Reisland, Ascherleben, Leipzig. 472 pl.

Skvortzov B.V. 1938. Subaerial diatoms from Pin-Chiang-Sheng Province, Manchoukuo. Philippine Journal of Science 65: 263-281.

SMITH W. 1853. A synopsis of the British Diatomaceae; with remarks on their structure, functions and distribution; and instructions for collecting and preserving specimens. Vol. 1. J. Van Voorst, London. 89 pp., 31 pls.

SмITH W. 1856. A synopsis of the British Diatomaceae; with remarks on their structure, functions and distribution; and instructions for collecting and preserving specimens. Vol. 2. J. Van Voorst, London. 107 pp.

TAvares J.J. 1924. O herbário do Colégio San Fiel. Brotéria 21: 82-87.

VAn Heurck H. 1880. Synopsis des diatomées de Belgique. Atlas. Ducaju \& Cie, Anvers. pls 1-30.

Van Heurck H. 1885. Synopsis des diatomées de Belgique. Texte. Martin Brouwers, Anvers. 235 pp.

VAn Heurck H. 1896. A treatise on the Diatomaceae (Trans. by W.E. Baxter). William Wesley, London. $558 \mathrm{pp}$.

Wetherbee R., Lind J.L., Burke J. \& Quatano R.S. 1998. The first kiss: establishment and control of initial adhesion by raphid diatoms. Journal of Phycology 34: 9-15.

WiLliams D.M. \& REID G. 2002. The diatom type slides and bibliography of John Carter (1908-1993). Bulletin of the Natural History Museum (Botany) 32: 137-151.

\section{Appendix \\ Bibliography and taxa described by $C$. Zimmermann}

We have found 37 publications by Zimmermann. All but two appear in the journal Broteria. In 1902, together with Father Cândido Mendes and Father Joaquim da Silva Tavares, Zimmermann founded Brotéria, which was devoted to the dissemination of research in the fields of botany and zoology, as well as popularizing science. The journal was named as a tribute to Félix d'Avelar Brotero (1744-1829), an eminent Portuguese botanist (Castel-Branco 2004). The journal began with the title Broteria. Revista de Sciencias Naturaes do Collegio de San Fiel. In 1907, it was split into three parts: Broteria. Revista de Sciencias Naturaes do Collegio de San Fiel, Serie de Vulgarização Scientifica, 
dedicated to popularising science; and Broteria. Revista de Sciencias Naturaes do Collegio de San Fiel, Série Botanica and Série Zoologica, dedicated to the disciplines of botany and zoology, respectively. From 1912, the title became simply Broteria. Revista Luso-Brazileira. From 1925, the popular science series was called Brotéria: Fé-Ciências-Letras. After 1932, its title was Brotéria: revista contemporânea de cultura; from 1965, it was Brotéria: revista de cultura; from 1970 Brotéria: cultura e informação; from 1999, it reverted to Brotéria: revista de cultura; finally, in 2002, becoming Brotéria: cristianismo e cultura, which is its title today. The botany and zoology series remained separate from 1907 to 1932, when they united as Brotéria: ciências naturais, changing its name to Brotéria: genética, now a journal dedicated to studies of genetics.

Zimmermann's articles in Brotéria have two pagination systems. Each separate article is given a conventional page number that corresponds to its place in the journal. In addition, each article is given another page number placed in brackets. This second number corresponds to the page number of article sequence such that any series of papers are number sequentially by series as well as by journal position. Thus, if reprints are bound together they will gain a continuous page sequence. In the references below, the numbers given in brackets refer to the pagination of individual articles in a set of related papers. For example, there are five parts to the series 'Catalogo das diatomaceas portuguezas'. The second part of the 'Catalogo' has page numbers in Brotéria 89-97; its page number in the 'Catalogo' series is 8-16.

All articles published in Brotéria are available online via the Digital Library of Real Jardín Botánico of Madrid (http://bibdigital.rjb.csic.es/ing/Volumenes.php-Libro=1527).

A portrait of Zimmermann can be found in Brotéria [Segundo $\mathrm{N}^{\circ}$ especial], 1927, fig. 1. Two species have been named after him: Placoneis zimmermannii Metzeltin \& Lange-Bertalot (Iconographia Diatomologica 5: 201, pl. 89: figs 10-13, 1998) and Cymbopleura zimmermannii Metzeltin \& Lange-Bertalot (Iconographia Diatomologica 18: p. 68, pl. 199, figs 16, 2007).

Zimmermann's taxon names are given below under the relevant publication. Some of his names appear in his publications without any authorities appended. It is likely that these were not intended as new names or new combinations, but referred to names already published and in use.

Because Zimmermann's specimen collections no longer exist it is not possible to examine the specimens and offer typifications. It would be possible to assign illustrations as types (ICBN Art. 37.4) but we have not done so as some of the illustrations are of ambiguous interpretation. Our list of names below has been corrected for any obvious nomenclatural errors (such as issues of priority) and, where we felt it would least cause problems, we have added new names for taxa described by Zimmermann using a preoccupied name. We have made no other taxonomic changes, but it is of note that some names (taxa) will need to be further examined with respect to both their taxonomy and their nomenclature to avoid problems in the future. For example, Zimmermann's taxon named Navicula mutica var. capitata has priority over two other taxa with the same name but his taxon is not that which is commonly understood to be Navicula mutica var. capitata.

Zimmermann C. 1902a. Microscopia vegetal. Brotéria. Revista de Sciencias Naturaes do Collegio de San Fiel 1: 49-75 [2nd edition 1907, pp. 1-27].

ZIMMERMANN C. 1902b. Observatorio metereologico do Collegio de San Fiel. Brotéria: Revista Sciencias Naturaes 1: 183-185 [2nd edition 1907].

ZIMMERMANN C. 1903. Microscopia vegetal. Brotéria. Revista de Sciencias Naturaes do Collegio de San Fiel 2: 5-40 [30-64].
Zimmermann C. 1903. O Epidascopio de Carlos Zeiss. Brotéria. Revista de Sciencias Naturaes do Collegio de San Fiel 2: 187-190.

Zimmermann C. 1904. Microscopia vegetal. Broteria. Revista de Sciencias Naturaes do Collegio de San Fiel 4: 137-159 [6587].

Zimmermann C. 1906a. Anatomia da Cecidia produzida pelo Trigonapsis mendesi, Tav., na Quercus lusitanica Lk. Broteria. Revista de Sciencias Naturaes do Collegio de San Fiel: Serie Botanica 5: 71-77 [1-7].

ZimmermanN C. 1906b. Variedades. Os Jesuítas e a Astronomía nos seculos 17 e 18 A proposito de um notavel trabalho ha póuco publicado (1). Broteria. Revista de Sciencias Naturaes do Collegio de San Fiel: Serie Botanica 5: 125-128.

ZimmermanN C. 1906c. Microscopia vegetal. Broteria. Revista de Sciencias Naturaes do Collegio de San Fiel 5: 229-242 [88-101].

Zimmermann C. 1906d. Catalogo das Diatomaceas portuguezas. I. Centuria. Broteria. Revista de Sciencias Naturaes do Collegio de San Fiel 5: 245-251 [1-7].

1. Navicula mesolepta Ehrenberg var. thermes (Ehrenberg) [=Navicula mesolepta var. termes (thermes) Van Heurck 1885: 80]

ZIMMERMANN C. 1907. Contribution à la conaissance des Cécidies du Kent. Broteria. Revista de Sciencias Naturaes do Collegio de San Fiel Zoologia 6: 103-108.

ZimmermanN C. 1909a. [Book Notices] Luisier, A. Note sur quelques Fissidens de la flore portugaise. Bulletin de la Société Portugaise des Sciences Naturelles. Lisbonne, Juillet 1907. Luisier, A. Note sur quelques mousses nouvelles pour la flore de Madère. Bulletin de la Société Portugaise des Sciences Naturelles. Lisbonne, Octobre 1907. Luisier, A. Les fruits du Campylopus polytrichoides De Not. Extrait du Bulletin de la Société Portugaise des Sciences Naturelles. Lisbonne, Décembre 1907. Luisier, A. Deuxième note sur les mousses de Madère. Extrait du Bulletin de la Société Portugaise des Sciences Naturelles, vol. ii, fasc. 1, 3 pag., 1908. Broteria. Revista de Sciencias Naturaes do Collegio de San Fiel 8: 79-80.

ZimmermanN C. 1909b. Catalogo das Diatomaceas portuguesas. II. Centuria. Broteria. Revista de Sciencias Naturaes do Collegio de San Fiel 8: 89-97 [8-16].

ZIMMERMANN C. 1909c. Catalogo das Diatomaceas portuguesas. III. Centuria. Broteria. Revista de Sciencias Naturaes do Collegio de San Fiel 8: 97-103 [17-22].

ZimMERMANN C. 1909d. Beitrag zur Kenntnis der DiatomaceenFlora der Inseln Madeira und Porto Santo. Broteria. Revista de Sciencias Naturaes do Collegio de San Fiel: Serie Botanica 8: 114-127 [1-14].

2. Achnanthes longipes f. major elongata C. Zimmermann 1909: 118, nom. invalid

3. Achnanthes longipes f. minor decussata C. Zimmermann 1909: 119, nom. invalid

4. Grammatophora serpentina f. minor C. Zimmermann 1909: 124, nom. invalid

5. Aulacodiscus amoenus var. madeirensis C. Zimmermann 1909: 126, pl. 9, fig. 1

Zimmermann C. 1910a. As diatomaceas: como se colhem e se preparam. Brotéria: serie de vulgarização científica 9: 42-51 [1-10].

Zimmermann C. 1910b. Catalogo das Diatomaceas portuguesas. IV. Centuria. Broteria. Revista de Sciencias Naturaes do Collegio de San Fiel: Serie Botanica 9: 95-102 [23-30].

6. Achnanthes longipes f. lata C. Zimmermann 1910: 99, nom. nud. 
7. Gomphonema gracile var. lanceolatum [possibly $=$ Gomphonema gracile var. lanceolata (lanceolatum) (Kützing) Cleve 1894: 183]

8. Cystopleura argus var. capitata C. Zimmermann 1910: 99, nom. nud.

9. Eunotia arcus var. curta [possibly =Eunotia arcus $\mathrm{f}$. curta Brun 1901: 7]

ZimMERMANN C. 1911. Beitrag zur Kenntnis der DiatomaceenFlora der Inseln Madeira und Porto Santo [II]. Broteria. Revista de Sciencias Naturaes do Collegio de San Fiel 9: 103-120 [15-32].

10. Navicula acrosphaeria [=Navicula acrosphaeria (Brébisson 1838: 19) Kützing 1844: 97, pl. 5, fig. 2]

11. Navicula forcipata var. punctata $[=$ Navicula forcipata var. punctata Cleve 1895: 65]

12. Navicula liber var. tenuistriata [=Navicula liber var. tenuistriata (Cleve 1894: 54) H. \& M. Peragallo 1897 1908: 72, pl. 9, fig. 7]

13. Gomphonema constrictum var. curta $[=$ Gomphonema constrictum var. curta (Grunow in Van Heurck 1880: 123, pl. 23, fig. 8) Van Heurck 1896: 270, pl. 7, fig. 298]

14. Gomphonema intricatum var. pumila $[=$ Gomphonema intricatum f. pumila Grunow in Van Heurck 1880: 24, fig. 35, 36]

ZimmermanN C. 1912. Bibliographia. Janet (Charles). Sporophyte et le gamotophyte du végétal. Le soma et le germen de l'insecte. 65 pag. in 8 Paris, 1912; Martins de Azededo Pimental (Dr. Antonio). Proeslea Paradoxa. Opúsculo em 8 de 10 pag., Rio de Janeiro, 1911. Brotéria. Revista Luso-Brazileira: Serie Botanica 10: 211.

ZimmermanN C. 1913. 1. Contribuição para o estudo das diatomaceas dos Estados Unidos do Brazil. Brotéria. Revista Luso-Brazileira: Serie Botanica 11: 149-164 [1-16].

ZimmermanN C. 1914a. 1a. Contribuição para o estudo das diatomaceas dos Estados Unidos do Brazil. Brotéria. Revista Luso-Brazileira: Serie Botanica 11: 5-12 [17-23].

Zimmermann C. 1914b. Catalogo das Diatomaceas portuguesas. Appendice. Broteria. Revista de Sciencias Naturaes do Collegio de San Fiel: Serie Botanica 12: 115-124 [31-40].

ZimmermanN C. 1914c. Contribuição para o conhecimento das diatomaceas da Provincia de Moçambique. Broteria. Revista Luso-Brazileira: Serie Botanica 12: 155-162 [1-8]

15. Scoliopleura westii var. stauroneiformis C. Zimmermann 1914: 156 [2]

ZimMERMANN C. 1915a. Algumas diatomaceas novas ou curiosas. Broteria. Revista Luso-Brazileira: Serie Botanica 13: 33-36 [1-4].

16. Ceratoneis arcus f. typica C. Zimmermann 1915: 36 [4], pl. 4 , fig. 9

17. Ceratoneis arcus f. trigibba C. Zimmermann 1915: 36 [4], pl. 4, fig. 10

18. Ceratoneis arcus f. arcuata C. Zimmermann 1915: 36 [4], pl. 4, fig. 11

19. Ceratoneis arcus f. semirecta C. Zimmermann 1915: 36 [4], pl. 4, fig. 12

20. Glyphodesmis varians C. Zimmermann 1915: 33 [1]

21. Glyphodesmis varians var. elegantula C. Zimmermann 1915: 34 [2], pl. 4, fig. 3

22. Glyphodesmis varians var. elongata C. Zimmermann 1915: 33, pl. 4, fig. 4

23. Glyphodesmis varians var. genuina C. Zimmermann 1915: 33, pl. 4, fig. 1

24. Glyphodesmis varians var. tumida C. Zimmermann 1915: 33, pl. 4, fig. 2
25. Gomphonema bipunctatum C. Zimmermann 1915: 34 [2], pl. 4: fig. 5 non Gomphonema bipunctatum Krasske, nom. illeg., 1943: 87 [= Gomphonema duplipunctatum Lange-Bertalot \& Reichardt in Lange-Bertalot et al. 1996: 88].

26. Eunotia fidelensis C. Zimmermann 1915: 35 [3], pl. 4: fig. 6

27. Eunotia pectinoides C. Zimmermann 1915: 35 [3], pl. 4: fig. 7 non Eunotia pectinoides J.R. Carter 1966: 454, pl. 9, figs 4, 5, 22 [=E. johncarterii D.M. Williams in Williams \& Reid 2002: 142]

28. Pleurosigma retusum C. Zimmermann 1915: 35 [3], pl. 4: fig. 6

ZIMMERMANN C. 1915b. II Contribuição para o estudo das diatomaceas dos Estados Unidos do Brazil. Broteria. Revista Luso-Brazileira: Serie Botanica 13: 37-56, est. IV-VII [5-24]

29. Eunotia didyma var. parallela C. Zimmermann 1915: 54 [22], pl. 6, fig. 14

ZIMMERMANN C. 1915c. II. Contribuição para o estudo das diatomaceas dos Estados Unidos do Brazil. Brotéria. Revista Luso-Brazileira: Serie Botanica 13: 6571 [25-31].

Zimmermann C.1915d. III. Contribuição para o estudo das diatomaceas dos Estados Unidos do Brazil. Brotéria. Revista Luso-Brazileira: Serie Botanica 13: 124-146 [31-53].

ZimmermanN C. 1916a. IV Contribuição para o estudo das diatomaceas dos Estados Unidos do Brazil. Brotéria. Revista Luso-Brazileira: Serie Botanica 14: 85-103 [58-75].

ZiMMERMANN C. 1916b. V Contribuição para o estudo das diatomaceas dos Estados Unidos do Brazil. Brotéria. Revista Luso-Brazileira: Serie Botanica 14: 130-157 [76-103].

ZIMMERMANN C. 1916c. Florula diatomologica do plankton superficial da bahia da Cidade do Salvador. Annaes do $5^{\circ}$ Congresso Brazileiro de Geographia 448-461, [figs] I-VIII.

ZimmermanN C. 1916d. Contribuição para o estudo da Flora Diatomologica do Lago chamado Dique da Bahia. Annaes do $5^{\circ}$ Congresso Brazileiro de Geographia, 470-484, [figs] I-IV.

30. Navicula bahiensis C. Zimmermann 1916: 473, P1. 1, fig. 2 (see below, taxon number 45)

31. Navicula placentula var. tropica C. Zimmermann 1916: 475 , Pl. 2, fig. 8 (see below, taxon number 44)

32. Navicula placentula var. tropica f. multicostata C. Zimmermann 1916: 475, Pl. 2, fig. 9 (see below, taxon number 44)

ZimMERMANN C. 1917a. Algumas diatomaceas novas ou curiosas [II]. Brotéria. Revista Luso-Brazileira: Serie Botanica 15: 5-7 [5-7].

33. Achnanthes solea C. Zimmermann 1917: 5, pl. 1, fig. 3 non Achnanthes solea Hustedt 1952: 389, figs 60-61 [=Achnanthes wellsiae Reimer in Patrick \& Reimer 1966: 255, pl. 16, figs 1517; =Astartiella wellsiae (Reimer in Patrick \& Reimer) Witkowski \& LangeBertalot in Moser, Lange-Bertalot \& Metzeltin 1998: 360; the online Catalogue of Diatom Names notes that the epithet should have been 'solea', possibly nom. illegit.]

34. Navicula henriquesii C. Zimmermann 1917: 6, pl. 1, fig. 4

35. Navicula lusitanica C. Zimmermann 1917: 5, pl. 1, figs 1, 2

36. Navicula umbilicata C. Zimmermann 1917: 7, pl. 1, fig. 6 =Navicula zimmermannii Gomes \& D.M. Williams, nom. nov. [non Navicula umbilicata Ehrenberg 1856: 328, 334, fig. 30]. 
37. Glyphodesmis sigmodea C. Zimmermann 1917: 7, pl. 1, fig. 5

ZIMMERMANN C. 1917b. VI Contribuição para o estudo das diatomaceas dos Estados Unidos do Brazil. Broteria. Revista Luso-Brazileira: Serie Botanica 15: 30-45, est. I [105-119].

38. Navicula placentula var. tropica f. multistriata C. Zimmermann 1917: 31

ZIMMERMANN C. 1918a. VII Contribuição para o estudo das diatomaceas dos Estados Unidos do Brazil. Brotéria. Revista Luso-Brazileira: Serie Botanica 16: 8-24, [figs] est. II-IV [120-136].

39. Navicula bahiensis C. Zimmermann 1918: 8 [120]

40. Plagiogramma itaparicanum C. Zimmermann 1918: 12 [124] (see below, number 71)

41. Mastogloia delicatula C. Zimmermann 1918: 13 [125] =Mastogloia zimmermannii Gomes \& D.M. Williams, nom. nov. [non Mastogloia delicatula Cleve 1893: 16, pl. 1, fig. 20] (see below, number 62).

ZIMMERMANN C. 1918b. Algumas diatomaceas novas ou curiosas. [III] Broteria. Revista Luso-Brazileira: Serie Botanica 16: 84-93, [figs] est. II-IV [8-17].

42. Achnanthes ambigua C. Zimmermann 1918: 93 [17], pl. 3, fig. 17

43. Amphora brasiliensis C. Zimmermann 1918: 87 [11], pl. 2, fig. 7

44. Brasiliella helix C. Zimmermann 1918: 91 [14], pl. 3, figs $13-16$

45. Campylodiscus guarujanus C. Zimmermann 1918: 89 [13], pl. 2, fig. 10

46. Cocconeis britannica var. tropica C. Zimmermann 1918: 90 [14], pl. 3, fig. 8

47. Coscinodiscus lineatus var. multiareolatus C. Zimmermann 1918: 93 [17], pl. 4, fig. 3

48. Cymbella capitata C. Zimmermann 1918: 93 [17], pl. 4, fig. 4 =Cymbella zimmermannii Gomes \& D.M. Williams, nom. nov. [non Cymbella capitata Pantocsek 1892, pl. 10, fig. 160, nec Cymbella capitata Brun 1895: pl. 14, fig. 27bis, 28, nec Cymbella capitata Héribaud 1903: 50, pl. 9, fig. 6].

49. Eunotia brasiliensis C.Zimmermann 1918: 86 [10], pl.2, fig. 4

50. Eunotia fragilarioides C. Zimmermann 1918: 87 [11], pl. 4 , fig. 5

51. Eunotia jaburuensis C. Zimmermann 1918: 86 [10], pl. 2, fig. 5

52. Frustulia lanceolata C. Zimmermann 1918: 87 [11], pl. 2, fig. $6=$ Frustulia zimmermannii Gomes \& D.M. Williams, nom. nov. [non Frustulia lanceolata Agardh 1827: 626, nec Frustulia lanceolata Berkeley 1833: 13, pl. 4, fig. 1]

53. Halurina itaparicana C. Zimmermann 1918: 90 [14], pl. 3, figs 4-5

54. Hantzschia amphioxys var. capitata C. Zimmermann 1918: 88 [12], pl. 2, fig. $8=$ Hantzschia amphioxys var. zimmermannii Gomes \& D.M. Williams, nom. nov. [non Hantzschia amphioxys var. capitata Pantocsek 1902: 104 (83), pl. 9, fig. 243 (=Nitzschia amphioxys var. capitata (Pantocsek) F.W. Mills 1934: 1194), nec Hantzschia amphioxys var. capitata (O. Müller) J. Frenguelli 1945: 196, pl. 12, fig. 8, nec Hantzschia amphioxys var. capitata (O. Müller) CleveEuler 1948: 49 (=Hantzschia amphioxys f. capitata O. Müller 1909: 34, pl. 2, fig. 26)]
Father Zimmermann, the first Brazilian diatomist

55. Hydrosera brasiliensis C. Zimmermann 1918: 94, pl. 4, fig. 6 (there appears to be a page missing from the journal as page 94 refers to the second page of an entirely different article, which lacks a title page, even though the index to the volume gives p. 94 as the source of the protologue for Hydrosera brasiliensis).

56. Mastogloia delicatula C. Zimmermann 1918: 91 [15], pl. 3, fig. 11

57. Navicula cancellata var. brasiliensis C. Zimmermann 1918: 85 [9], pl. 3 , fig. 6

58. Navicula elliptica var. tropica C. Zimmermann 1918: 85 [9], pl. 3, fig. $3=$ Diploneis elliptica var. tropica (C. Zimmermann) Frenguelli 1933: 414, pl. 4, fig. 9

59. Navicula fatigans C. Zimmermann 1918: 85 [9], pl. 3, fig. 10

60. Navicula formosa var. jaguaripensis C. Zimmermann 1918

61. Navicula guarujana C. Zimmermann 1918: 84 [8], pl. 2, fig. 2

62. Navicula sobralensis C. Zimmermann 1918: 84 [8],pl. 2 , fig. 1

63. Navicula submissa C. Zimmermann 1918: 85 [9], pl. 3, fig. 12

64. Navicula torpedo C. Zimmermann 1918: 86 [10], pl. 4, fig. 2

65. Plagiogramma itaparicanum C. Zimmermann 1918: 91 [15], pl. 3, fig. 9

66. Pleurosigma brasiliense C. Zimmermann 1918: 90 [14], pl. 3, fig. 2

67. Pleurosigma itaparicanum C. Zimmermann 1918: 89 [13], pl. 3, fig. 1[=Gyrosigma itaparicanum (C. Zimmermann) Andrade \& Teixeira 1957: 183, pl. 3, fig. 1]

68. Rhaphoneis (Raphoneis) itaparicana C. Zimmermann 1918: 90 [14], pl. 3, fig. 7

69. Schizostauron brasiliense C. Zimmermann 1918: 86 [10], pl. 2, fig. 3

70. Stenoneis radiata C. Zimmermann 1918: 93 [17], pl. 4, fig. 1

ZIMMERMANN C. 1918c. VIII Contribuição para o estudo das diatomaceas dos Estados Unidos do Brazil. Brotéria. Revista Luso-Brazileira: Serie Botanica 16: 113-122 [138-146].

ZIMMERMANN C. 1919b. Quelques Diatomées nouvelles ou curieuses. Brotéria. Revista Luso-Brazileira: Serie Botanica 17: 97-100, [figs] planche 3 (5) [21-24].

71. Achnanthes lanceolata var. brasiliensis C. Zimmermann 1919: 99 [23], pl. 3 (5), fig. 8

72. Fragilaria undata var. brasiliensis C. Zimmermann 1919: 100 [24], pl. 3(5), fig. 7

73. Navicula cardinaliculus var. margaritacea C. Zimmermann 1919: 97 [21], pl. 3(5), fig. 9

74. Navicula jequitinhonhae C. Zimmermann 1919: 98 [22], pl. 3(5), fig. 10

75. Navicula mutica var. capitata C. Zimmermann 1919: legend to pl. 3, fig. 4 non Navicula mutica var. capitata Østrup in Héribaud 1920: 53, pl. 7, fig. 17, nec Navicula mutica var. capitata Hustedt in Schmidt 1936: pl. 405, figs 35-36, invalid, nec Navicula mutica var. capitata Hustedt 1937: 233, pl. 17, fig. 5 (=N. mutica var. distinguenda Hustedt 1939: $381=N$. nivalis Ehrenberg 1853: 528]

76. Navicula mutica var. rhombica C. Zimmermann 1919: 99 [23], pl. 3(5), fig. 4 [as Navicula mutica var. capitata on legend to pl. 3, fig. 4] non Navicula mutica var. rhombica Skvortzov 1938: 270, pl. 2, figs 16, 17 
77. Navicula torrendi C. Zimmermann 1919: 98 [22], pl. 3(5), figs $12=$ Pinnularia torrendi (C. Zimmermann) Frenguelli 1933: 399, pl. 3, fig. 16

78. Navicula torrendi var. capitata C. Zimmermann 1919: 98 [22], pl. 3 (5), fig. 3 =Pinnularia torrendi var. capitata (C. Zimmermann) Frenguelli 1933: 399, pl. 3, fig. 16
79. Navicula torrendi var. capitata f. nana C. Zimmermann 1919: 99 [23], pl. 3(5), fig. 5

80. Navicula torrendi f. typica C. Zimmermann 1919: 98, pl. 3(5), figs 1-2

ZIMMERMANN C. 1919a. IX Contribuição para o estudo das diatomaceas dos Estados Unidos do Brazil. Brotéria. Revista Luso-Brazileira: Serie Botanica 17: 5-16 [147-158]. 